\title{
Article \\ Synthesis, Crystal Structure, and Electrochemical Properties of an Isopolyoxovanadate Compound Modified Transition-Metal Complex Based on $\left[\mathrm{V}_{4} \mathrm{O}_{12}\right]^{4-}$
}

\author{
Yongxiu Wang, Bingjie Zhang, Huili Guo, Yanhua Fan, Haiyan Li, Jingyu Pang *, Dongbin Dang * and Yan Bai *
}

check for updates

Citation: Wang, Y.; Zhang, B.; Guo, H.; Fan, Y.; Li, H.; Pang, J.; Dang, D.; Bai, Y. Synthesis, Crystal Structure, and Electrochemical Properties of an Isopolyoxovanadate Compound Modified Transition-Metal Complex Based on $\left[\mathrm{V}_{4} \mathrm{O}_{12}\right]^{4-}$. Catalysts 2022, 12, 108. https://doi.org/10.3390/ catal12020108

Academic Editor: Antonia Iazzetti

Received: 16 November 2021

Accepted: 10 January 2022

Published: 18 January 2022

Publisher's Note: MDPI stays neutral with regard to jurisdictional claims in published maps and institutional affiliations.

Copyright: (c) 2022 by the authors. Licensee MDPI, Basel, Switzerland. This article is an open access article distributed under the terms and conditions of the Creative Commons Attribution (CC BY) license (https:/ / creativecommons.org/licenses/by/ $4.0 /)$.

\begin{abstract}
Henan Key Laboratory of Polyoxometalate Chemistry, College of Chemistry and Chemical Engineering, Henan University, Kaifeng 475004, China; wangyongxiu1229@163.com (Y.W.); bingjie_Z@163.com (B.Z.); ghlhenu@163.com (H.G.); fanyanhua9080@163.com (Y.F.); lihaiyan@henu.edu.cn (H.L.)

* Correspondence: pjy@henu.edu.cn (J.P.); dangdb@henu.edu.cn (D.D.); baiyan@henu.edu.cn (Y.B.); Tel.: +86-183-6288-7131 (J.P.); +86-134-0378-1602 (D.D); +86-136-6378-3688 (Y.B.)
\end{abstract}

\begin{abstract}
A new isopolyoxovanadate compound $\left[\mathrm{Zn}(\text { phen })_{3}\right]_{2} \cdot\left(\mathrm{V}_{4} \mathrm{O}_{12}\right) \cdot$ phen $\cdot 20 \mathrm{H}_{2} \mathrm{O}$ (phen $=1$,10phenathroline) (1) has been synthesized in aqueous solution and characterized using IR and UV/Vis spectroscopy, elemental analysis, thermal gravimetric analysis, powder, single-crystal X-ray diffractions, and field emission scanning electron microscopy. The molecular structure of $\mathbf{1}$ exists as two kinds of $\left[\mathrm{V}_{4} \mathrm{O}_{12}\right]^{4-}$ polyoxoanions: distorted chair-like and coplanar conformations, two independent $\left[\mathrm{Zn}(\mathrm{phen})_{3}\right]^{2+}$ units and free phen. In the solid state, compound $\mathbf{1}$ forms a stable three-dimensional supramolecular structure through electrostatic interactions, $\pi-\pi$ stacking interactions and multiform hydrogen bonds. The electrocatalytic activity and determination of DA of compound $\mathbf{1}$ have been studied by cyclic voltammetry and differential pulse voltammetry, respectively.
\end{abstract}

Keywords: isopolyoxovanadate; supramolecular structure; electrocatalytic; detection of DA

\section{Introduction}

Polyoxometalates (POMs) are early transition metal-oxygen clusters composed of group VI and group V elements including molybdenum, tungsten, vanadium, niobium and tantalum [1-4]. POMs possess large number of negative with unique chemical composition and structural diversity, which can be considered to be one of the ideal candidates for electrocatalyst [5]. Among POMs, isopolyoxovanadates are regarded as very important because of their outstanding magnetic and electronic properties and the profound impact of their long-term promise as oxidation catalysts [6]. In comparison with other POMs, the vanadium oxygen clusters exhibit unique structure and excellent performance due to the variable valence (from +3 to +5$)$ and abundant coordination configurations $\left(\mathrm{VO}_{4}\right.$ tetrahedra, $\mathrm{VO}_{5}$ square pyramid and trigonal bipyramid, $\mathrm{VO}_{6}$ octahedra) of vanadium atom [7-12]. Various isopolyoxovanadates including $\left[\mathrm{V}_{2} \mathrm{O}_{7}\right]^{4-},\left[\mathrm{V}_{3} \mathrm{O}_{9}\right]^{3-},\left[\mathrm{V}_{4} \mathrm{O}_{12}\right]^{4-},\left[\mathrm{V}_{6} \mathrm{O}_{17}\right]^{4-},\left[\mathrm{V}_{8} \mathrm{O}_{23}\right]^{6-}$, $\left[\mathrm{V}_{10} \mathrm{O}_{28}\right]^{6-},\left[\mathrm{V}_{12} \mathrm{O}_{33}\right]^{6-}\left[\mathrm{V}_{14} \mathrm{O}_{36}\right]^{4-},\left[\mathrm{V}_{15} \mathrm{O}_{36}\right]^{5-},\left[\mathrm{V}_{16} \mathrm{O}_{38}\right]^{4-},\left[\mathrm{V}_{18} \mathrm{O}_{42}\right]^{12-}$ and so on, have been reported in the previous papers [13-25].

In recent years, the studies of $\left[\mathrm{V}_{4} \mathrm{O}_{12}\right]^{4-}$-based compounds modified by transition-metal complexes have been made abundant fruit, including $\left[\mathrm{Cu}(\mathrm{phen})_{3}\right]_{2} \mathrm{~V}_{4} \mathrm{O}_{12} \cdot \mathrm{phen} \cdot 22 \mathrm{H}_{2} \mathrm{O}$, $\left.\left[\mathrm{M}^{\mathrm{II}} \text { (phen }\right)_{3}\right]_{2} \mathrm{~V}_{4} \mathrm{O}_{12} \cdot$ phen $\cdot 22 \mathrm{H}_{2} \mathrm{O}\left(\mathrm{M}^{\mathrm{II}}=\mathrm{Co}, \mathrm{Ni}\right)$ and $\left[\mathrm{Fe}(\text { phen })_{3}\right]_{2}\left[\right.$ phen] $\left[\mathrm{V}_{4} \mathrm{O}_{12}\right] \cdot 19 \mathrm{H}_{2} \mathrm{O}$, in which the $\left[\mathrm{V}_{4} \mathrm{O}_{12}\right]^{4-}$ with coplanar, boat and chair conformations is considered to be a remarkable class of anions [26-28]. Among them, $\left[\mathrm{V}_{4} \mathrm{O}_{12}\right]^{4-}$ anion in only a few compounds, $\left\{\left[\mathrm{Ru}(\text { phen })_{3}\right]_{2}\left[\mathrm{~V}_{4} \mathrm{O}_{12}\right]\right\} \cdot 13 \mathrm{H}_{2} \mathrm{O}, \mathrm{V}^{\mathrm{IV}}{ }_{2} \mathrm{~V}_{4} \mathrm{O}_{14}(\mathrm{mIM})_{8}$ and $\left[\left(\mathrm{CH}_{3}\right)_{3} \mathrm{CNH}_{3}\right]_{4}\left[\mathrm{~V}_{4} \mathrm{O}_{12}\right]$, adopted coplanar configuration $[6,16,17]$. However, of even greater concern is two different conformations occur in a structure. To our knowledge, there is an example of $\left[\left\{\mathrm{Mn}\left(2,2^{\prime} \text {-bidy }\right)_{2}\right\}_{2} \mathrm{~V}_{4} \mathrm{O}_{12}\right]$ with boat and chair conformations [29]. Based on our current research on POM-based compounds [30-35], we report the synthesis and structural characterization of a new isopolyoxovanadate-based hybrid $\left[\mathrm{Zn}(\mathrm{phen})_{3}\right]_{2} \cdot\left(\mathrm{V}_{4} \mathrm{O}_{12}\right) \cdot$ phen $\cdot 20 \mathrm{H}_{2} \mathrm{O}$ 
(phen = 1,10-phenathroline) $(\mathbf{1})$, in which $\left[\mathrm{V}_{4} \mathrm{O}_{12}\right]^{4-}$ anions present two types of conformations: chair form and coplanar form. The electrochemical experiments show that compound 1 displays the obvious electrocatalytic performance for the oxidation of dopamine (DA) and ascorbic acid (AA). Furthermore, detection of DA was determined for 1-modified GCE.

\section{Results and Discussion}

Characterization of compound 1 Single-crystal $X$-ray diffraction analysis indicates that compound 1 belongs to triclinic crystal system with space group $P^{-} 1$. Compound 1 contains two $\left[\mathrm{V}_{4} \mathrm{O}_{12}\right]^{4-}$ anions, two $\left[\mathrm{Zn}(\text { phen })_{3}\right]^{2+}$ cations and a phen, along with 20 free water molecules (Figure 1). Each $\left[\mathrm{V}_{4} \mathrm{O}_{12}\right]^{4-}$ anion is comprised of four corner-sharing distorted $\left\{\mathrm{VO}_{4}\right\}$ tetrahedra. Interestingly, the two $\left[\mathrm{V}_{4} \mathrm{O}_{12}\right]^{4-}$ anions within compound 1 show different conformations (Figure S1). The $\left\{\mathrm{V}_{4} \mathrm{O}_{4}\right\}$ ring (V1, V2, V1a and V2a) is chairlike similar to those of compounds with the V-O distances of 1.611(3)-1.786(3) A [14]. The V$\mathrm{O}_{\mathrm{t}}$ distances (1.611(3)-1.639(3) $\AA$ ) are shorter than the $\mathrm{V}-\mathrm{O}_{\mathrm{b}}$ distances $(1.764(3)-1.786(3) \AA)$. The O-V-O bond angles vary from $107.49(16)$ to $112.06(19)^{\circ}$, close to $109.28^{\circ}$ of regular tetrahedral angle. However, the four $\mu_{2}-\mathrm{O}$ atoms lie in the same plane as four vanadium atoms nearly coplanar in $\left\{\mathrm{V}_{4} \mathrm{O}_{4}\right\}(\mathrm{V} 3, \mathrm{~V} 4, \mathrm{~V} 3 \mathrm{~b}$ and $\mathrm{V} 4 \mathrm{~b})$ ring. The average $\mathrm{V}-\mathrm{O}$ distance is $1.63 \AA$ for $\mathrm{V}-\mathrm{O}_{\mathrm{t}}$ and $1.78 \AA$ for $\mathrm{V}-\mathrm{O}_{\mathrm{b}}$, respectively. All the $\mathrm{O}-\mathrm{V}-\mathrm{O}$ bond angles varied from $107.29(16)$ to $112.23(14)^{\circ}$. These results indicate that the $\left\{\mathrm{V}_{4} \mathrm{O}_{4}\right\}$ ring (V3, V4, V3b and V4b) is nearly coplanar which are highly consistent with compounds in the references $[16,17]$.

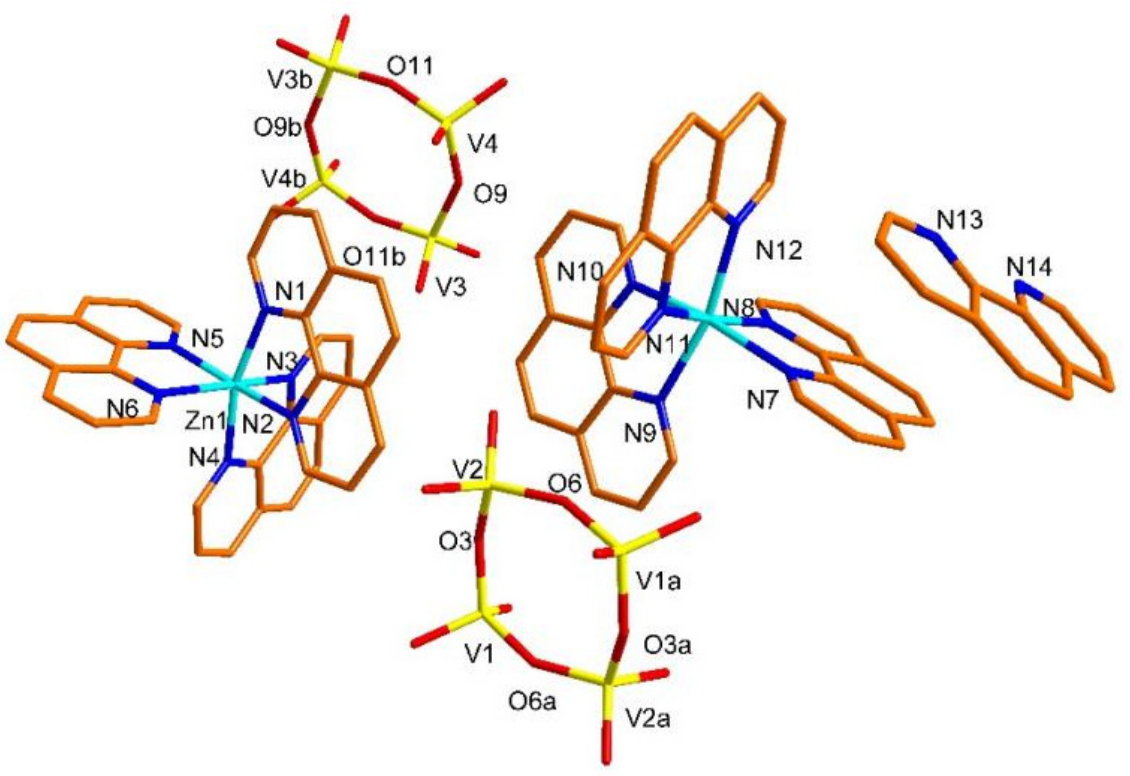

Figure 1. The crystal structure of compound $\mathbf{1 .}$

Compound 1 contains two crystallographically independent zinc (II) centers with similar six-coordinated $\mathrm{N}_{6}$ environment. $\mathrm{Zn}(1)$ and $\mathrm{Zn}(2)$ are bonded to six nitrogen atoms from three phen molecules, forming octahedral $\left\{\mathrm{ZnN}_{6}\right\}$ coordination configuration with the average $\mathrm{Zn}-\mathrm{N}$ distance of $2.16 \AA$. It is noteworthy that there are five kinds of face-to-face $\pi \cdots \pi$ stacking interactions among adjacent phen units from two $\left[\mathrm{Zn}(\mathrm{phen})_{3}\right]^{2+}$ cations and free phen, forming a one-dimensional structure (Figure 2). A detailed structural analysis revealed that four $\pi-\pi$ stacking interactions are found between two phen (N7, N8 and $\mathrm{N} 11, \mathrm{~N} 12)$ from $\mathrm{Zn}(2)$-phen unit and two phen (N3, N4 and N5, N6) from two adjacent $\mathrm{Zn}(1)$-phen units, respectively. Moreover, between the phen (N7, N8) from Zn(2)-phen unit and free phen $(\mathrm{N} 13, \mathrm{~N} 14)$ are also exit $\pi-\pi$ stacking interaction, which makes the onedimensional structure more stable. The inter-planar shortest separations of atom $\cdots$ atom and the centroid . . centroid are $3.59 \AA$ and $3.87 \AA, 3.81 \AA$ and $3.92 \AA, 3.55 \AA$ and $3.68 \AA$, $3.68 \AA$ and $3.80 \AA, 3.73 \AA$ and $3.88 \AA$ respectively, along with the dihedral angles are $15.9^{\circ}$, 
$5.6^{\circ}, 5.4^{\circ}, 6.3^{\circ}$ and $7.2^{\circ}$. In addition, there are multiple forms of $\mathrm{C}-\mathrm{H} \cdots \mathrm{O}$ hydrogen bonds in the crystal structure (Table 1), which are beneficial to the stability of three-dimensional supramolecular structure (Figure 3 and Figure S2).

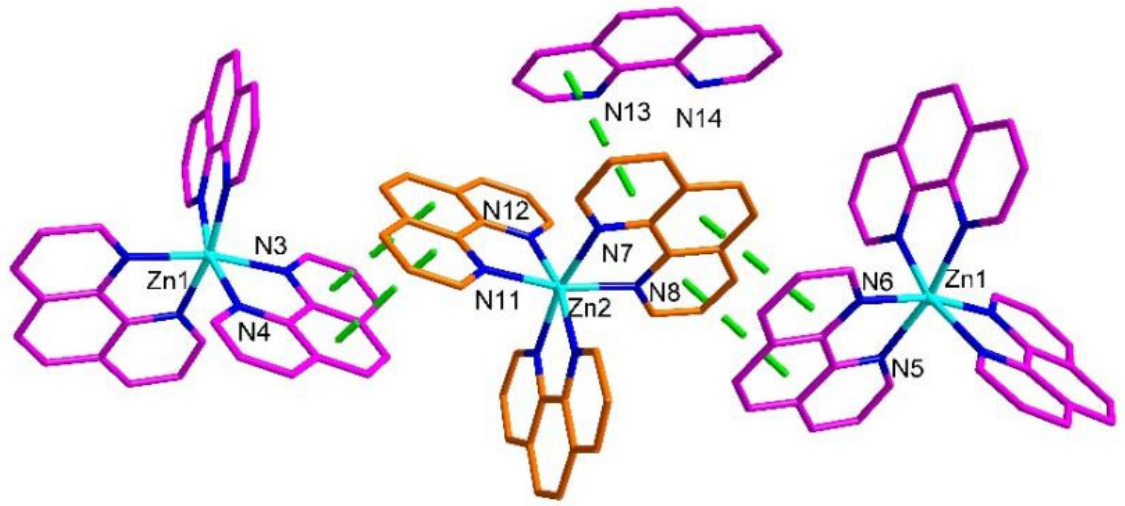

Figure 2. The $\pi-\pi$ interactions of compound 1 .

Table 1. Hydrogen bonding interactions ( $\mathrm{A}$ and deg) for $\mathbf{1}$.

\begin{tabular}{|c|c|c|c|c|c|}
\hline $\mathbf{D}-\mathbf{H} \cdots \mathbf{A}$ & $\mathrm{d}(\mathrm{D}-\mathrm{H})$ & $\mathbf{d}(\mathbf{H} \cdots \mathbf{A})$ & $\mathrm{d}(\mathrm{D} \cdots \mathrm{A})$ & $\angle$ (DHA) & $\begin{array}{c}\text { Symmetry } \\
\text { Codes of Atom A }\end{array}$ \\
\hline C3-H3A $\cdots$ O10 & 0.93 & 2.57 & 3.3082 & 137 & \\
\hline C6-H6A $\cdots$ O5 & 0.93 & 2.57 & 3.4115 & 151 & \\
\hline C8-H8A $\cdots$ O3 & 0.93 & 2.59 & 3.4398 & 152 & \\
\hline C18-H18A $\cdots$ O5f & 0.93 & 2.30 & 3.1732 & 157 & $1+x, y, z$ \\
\hline C51-H51A ‥ O2 & 0.930 & 2.48 & 3.3133 & 149 & \\
\hline C56-H56A ‥ O9 & 0.93 & 2.56 & 3.4092 & 152 & \\
\hline C61-H61A …6а & 0.93 & 2.44 & 3.2299 & 143 & $1-x, 1-y$ \\
\hline C66-H66A ‥ O7i & 0.93 & 2.35 & 3.2063 & 154 & $-1+x, y, z$ \\
\hline C68-H68A $\cdots$ O8i & 0.93 & 2.58 & 3.4166 & 150 & $-1+x, y, z$ \\
\hline
\end{tabular}

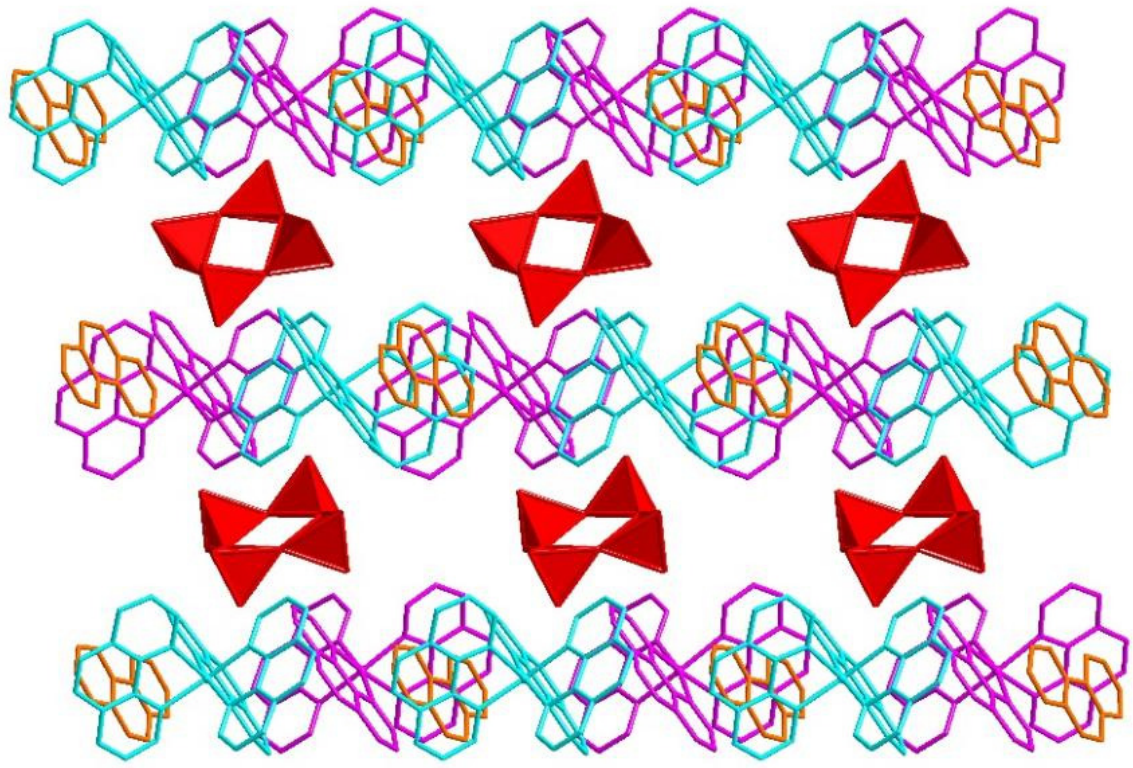

Figure 3. The 3D supramolecular framework in compound $\mathbf{1 .}$

To certify the purity and crystallinity of the obtained sample, compound $\mathbf{1}$ was further authenticated by X-ray powder diffraction. The characteristic peak positions between 
experimental patterns and the simulated are consistent, indicating that compound $\mathbf{1}$ is purity (Figure S3). The differences in reflection intensity are probably due to the preferred orientation or the efflorescence of the crystals. Moreover, compared with the XRD pattern ( $2 \theta$ from $5^{\circ}$ to $45^{\circ}$ ) of compound 1 (Figure S3 middle) and phen (Figure S3 bottom), some diffractive peaks obtained at near $5.7^{\circ}, 7.2^{\circ}, 7.9^{\circ}$ and $8.9^{\circ}$ were assigned to $\left[\mathrm{V}_{4} \mathrm{O}_{12}\right]^{4-}$ anions, whereas the diffractive peaks at $10.1^{\circ}, 14.5^{\circ}, 15.3^{\circ}, 17.4^{\circ}$ and $20.1^{\circ}$ were ascribed to phen.

The IR spectrum of compound 1 shows a broad absorption peak at $3400 \mathrm{~cm}^{-1}$, which is attributed to the $v(\mathrm{OH})$ stretching frequency, indicating the presence of water molecule. The characteristic absorption peaks at 1625, 1585, 1518, 1426, 1340, 1146, $1104 \mathrm{~cm}^{-1}$ should be ascribed to vibrations of $\mathrm{C}-\mathrm{C}$ and $\mathrm{N}-\mathrm{C}$ bonds from phen ring in compound $\mathbf{1}$ (Figure S4). The result presents appropriate shift compared to phen, showed at 1641, 1585, 1502, 1421, $1344,1136,1091 \mathrm{~cm}^{-1}$, which indicates that the two $\mathrm{N}$ atoms of phen have coordinated with the zinc ions [36,37]. The intensity peaks at 940,910 and $867 \mathrm{~cm}^{-1}$ are ascribed to the $v\left(\mathrm{~V}-\mathrm{O}_{\mathrm{t}}\right)$, while the peaks appeared at 846,805 and $724 \mathrm{~cm}^{-1}$ show the vibrations of $v(\mathrm{O}-\mathrm{V}-\mathrm{O})$, which is consistent with relevant references $[9,16]$.

The UV-vis absorption spectrum of compound $\mathbf{1}$ has been researched at the range of $200-800 \mathrm{~nm}$ in the solid state. There is obvious absorption throughout the test range. The maximum values of the two strong absorption peaks are located at $340 \mathrm{~nm}$ and $518 \mathrm{~nm}$. The higher energy absorption peak at $340 \mathrm{~nm}$ is caused by the $\mathrm{n} \rightarrow \pi^{*}$ transitions of $\left[\mathrm{Zn}(\mathrm{phen})_{3}\right]^{2+}$ cations. The coordination of phenanthroline with zinc can enhance the conjugation degree of the whole system, so that the energy absorption peak appears red shift (Figure S5). The lower energy peak corresponds to the $\mathrm{O} \rightarrow \mathrm{V}$ charge transfer in the polyoxoanion structure [38]. The characteristic peak in the UV $(340 \mathrm{~nm})$ region is stronger than in the visible $(518 \mathrm{~nm})$ region, which is highly consistent with those relevant compounds.

To further identify the morphology of compound 1, scanning electron microscopy (SEM) was investigated by daubing the sample suspension onto the Si foil. As shown in Figure S6, it can be observed from the magnified SEM that compound $\mathbf{1}$ exhibited a smooth rhomboid crystal.

The thermogravimetric curve of compound 1 was obtained at a heating rate of $10{ }^{\circ} \mathrm{C}$ min $^{-1}$ from 25 to $1000{ }^{\circ} \mathrm{C}$ under $\mathrm{N}_{2}$ atmosphere. As shown in Figure S7, the first step, at the range of $25-210{ }^{\circ} \mathrm{C}$, is attributed to the loss of water from the crystal. The observed weight loss $(15.75 \%)$ is consistent with the calculated value $(16.76 \%)$. The weight loss of $58.25 \%$ (calcd. $58.72 \%$ ) at the range from $210{ }^{\circ} \mathrm{C}$ to $980{ }^{\circ} \mathrm{C}$ is ascribed to the eliminate of organic ligands phen. With the increasing of compound $\mathbf{1}$ weight loss and lasting for the temperature limit after $980^{\circ} \mathrm{C}$, the inorganic cluster collapse gradually, which is consistent with the molecular composition of compound 1.

First step: $\left[\mathrm{Zn}(\text { phen })_{3}\right]_{2} \cdot\left(\mathrm{V}_{4} \mathrm{O}_{12}\right) \cdot$ phen $\cdot 20 \mathrm{H}_{2} \mathrm{O} \stackrel{-\mathrm{H}_{2} \mathrm{O}}{\rightarrow}\left[\mathrm{Zn}(\text { phen })_{3}\right]_{2} \cdot\left(\mathrm{V}_{4} \mathrm{O}_{12}\right) \cdot$ phen

Second step: $\left[\mathrm{Zn}(\text { phen })_{3}\right]_{2} \cdot\left(\mathrm{V}_{4} \mathrm{O}_{12}\right) \cdot$ phen $\stackrel{- \text { phen }}{\rightarrow} 2 \mathrm{Zn}^{2+}+\left[\mathrm{V}_{4} \mathrm{O}_{12}\right]^{4-}$

Last step: $2 \mathrm{Zn}^{2+}+\left[\mathrm{V}_{4} \mathrm{O}_{12}\right]^{4-} \rightarrow 4 \mathrm{VO}_{2}+2 \mathrm{ZnO}$

Electrochemical Properties The electrochemical properties of POVs have aroused eager attention, owing to its feasible application in the electrocatalysis [39]. The electrochemical behaviors of compound $\mathbf{1}$ modified carbon paste electrode (CPE-1) were carried out in $\mathrm{H}_{2} \mathrm{SO}_{4}$ aqueous solution $\left(0.1 \mathrm{~mol} \cdot \mathrm{L}^{-1}\right)$ at the range of $-0.90 \mathrm{~V} \sim 0.90 \mathrm{~V}$. Compound 1 exhibits two pairs of reversible redox peaks (I-I' and II-II') with $\mathrm{E}_{1 / 2}$ values of $+0.291 \mathrm{~V}$ and $-0.483 \mathrm{~V}$, which are attributable to a one-electron $\mathrm{V}^{\mathrm{V}} \rightarrow \mathrm{V}^{\mathrm{IV}}$ and a two-electron $\left(\mathrm{V}^{\mathrm{V}} \rightarrow \mathrm{V}^{\mathrm{III}}\right)$, respectively [40] (Figure 4). Moreover, as the scan rate increased, the potential of cathodic peaks shifted to more negative direction and the corresponding potential of anodic peaks toward the positive direction, respectively, suggesting that redox processes irreversible is increasing. 


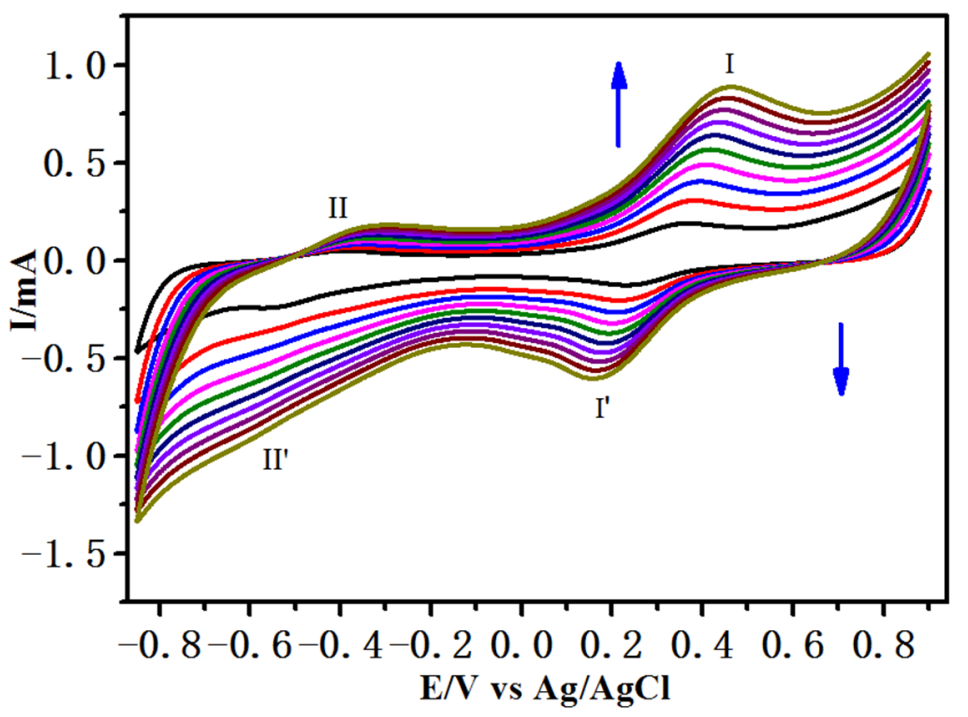

Figure 4. The cyclic voltammograms of the CPE- 1 in $\mathrm{H}_{2} \mathrm{SO}_{4}$ aqueous solution $\left(0.1 \mathrm{~mol} \cdot \mathrm{L}^{-1}\right)$ at different scan rates (from inner to outer: 20, 40, 60, 80, 100, 120, 140 and 160, 180, $200 \mathrm{mV} \cdot \mathrm{s}^{-1}$ ).

As is well-known, dopamine (DA) and ascorbic acid (AA) are vital components in the human diet and participate in numerous vital responses. Therefore, their detection is of great significance in food industry, medicine and clinical research. Among various techniques of detection, electrochemical is one of the most popular methods because of its quick and sensitive response. The electrocatalytic oxidation of DA and AA is a two-electron transfer process and they have similar electrocatalytic process, which is the conversion of two hydroxyl groups to two carbonyl groups (Scheme 1) [41]. Recent years, a great deal of POM-based inorganic-organic compounds have been studied on electrocatalytic of DA and AA [42,43]. To the best of our knowledge, this is the first $\left[\mathrm{V}_{4} \mathrm{O}_{12}\right]^{4-}$-based compound reported for the study of electrocatalytic properties. Based on it, the electrocatalytic conductivity of DA and $\mathrm{AA}$ in $\mathrm{H}_{2} \mathrm{SO}_{4}\left(0.1 \mathrm{~mol} \cdot \mathrm{L}^{-1}\right)$ aqueous solution was investigated using $\mathrm{CPE}-1$ as the working electrode (Figure 5). With the increase of DA and AA concentration, the oxidation peak currents increased, and the corresponding reductive peak currents decreased. It is worth noting that the changes of redox peaks for DA is more obvious than that for AA. The results indicated that compound 1 has better electrocatalytic activity for DA than AA. That may be because the ester group in the structure of ascorbic acid has an attractive effect on electrons, resulting in the hindrance of electron transfer during the reaction process. Furthermore, the stability of compound 1 was investigated by cyclic voltammetry in $\mathrm{H}_{2} \mathrm{SO}_{4}$ aqueous solution containing $20 \mathrm{mM}$ AA (Figure S8). The result showed that the decay rate of current reaches $0.5 \%$ after 100 consecutive cycles, which manifest that compound $\mathbf{1}$ is a stable electrocatalyst.

DA

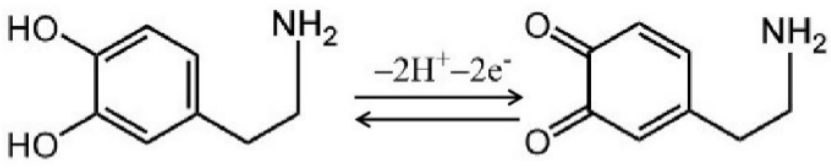

AA

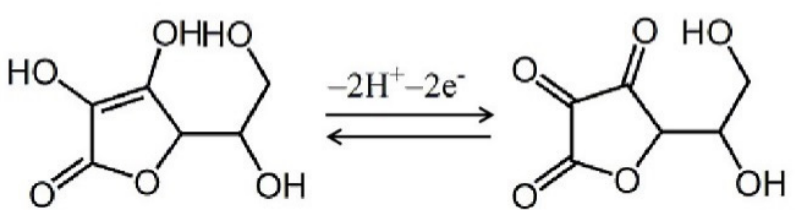

Scheme 1. Electron transfer process of DA and AA. 

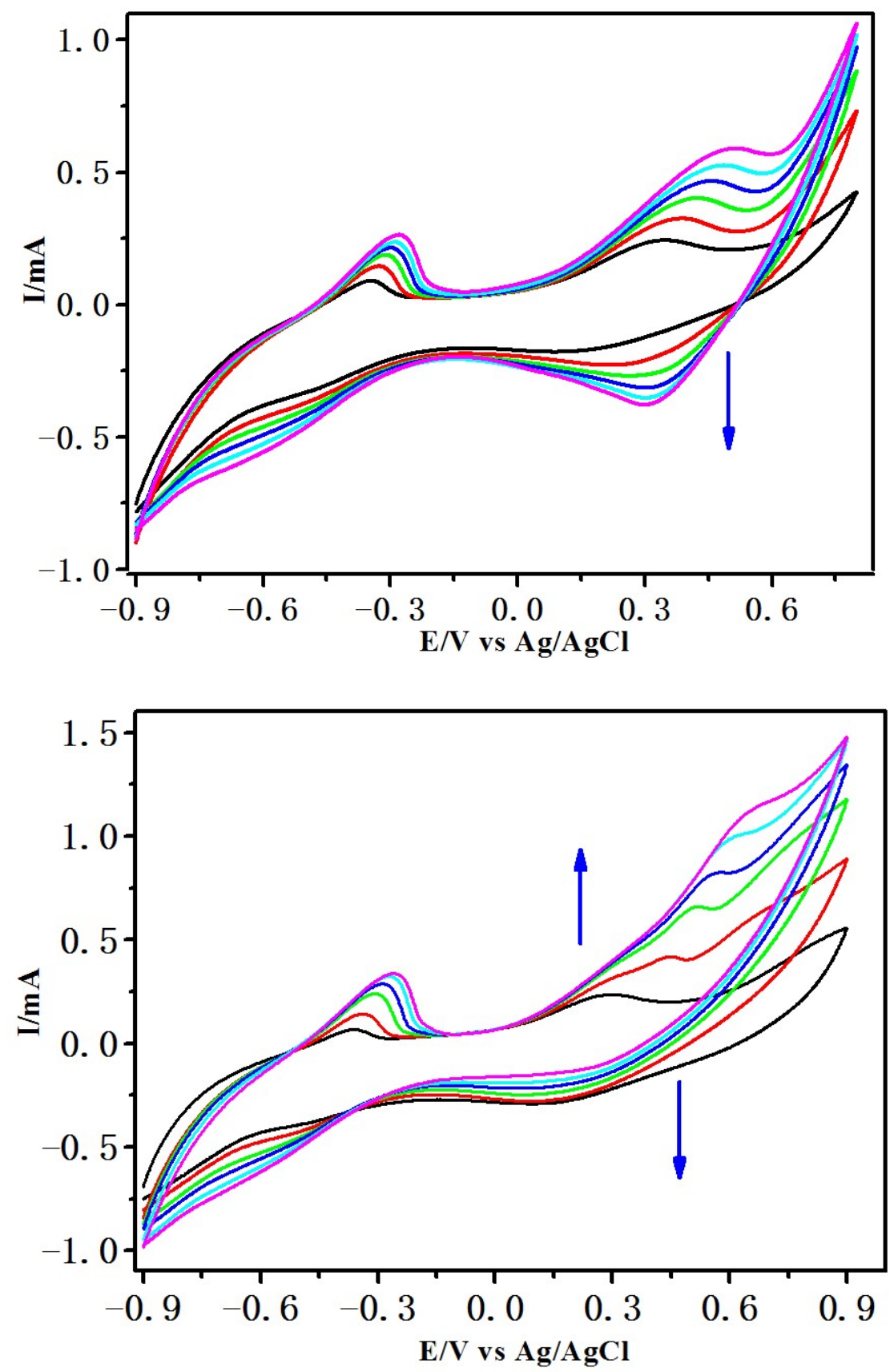

Figure 5. The cyclic voltammograms of the CPE-1 in $\mathrm{H}_{2} \mathrm{SO}_{4}$ aqueous solution $\left(0.1 \mathrm{~mol} \cdot \mathrm{L}^{-1}\right)$ containing DA (top) and AA (down), scan rate: $100 \mathrm{mV} \cdot \mathrm{s}^{-1}$ (the arrow up or down represents the increase of DA and AA concentration from inner to outer: 0, 20, 40, 60, 80 and $100 \mathrm{mM}$ ).

Compared with cyclic voltammetry method, the differential pulse voltammetry (DPV) method can obtain stronger signal by eliminating the non-Faradaic currents that occur with $\mathrm{CV}$, which has better sensitivity for the detection of small biomolecules. Therefore, the DPV responsive curves for 1-modified GCE toward DA were carried out in $\mathrm{H}_{2} \mathrm{SO}_{4}$ aqueous solution $\left(0.1 \mathrm{~mol} \cdot \mathrm{L}^{-1}\right)$ by varying the concentration of DA. Apparently, an oxidation peak assigned to DA appears at $+0.54 \mathrm{~V}$ and the responsive peak currents gradually rise with increasing concentration of DA. As shown in Figure 6, the response peak current of DPV is linear with the concentration of DA, which is consistent with the linear equation of $\mathrm{I}(\mu \mathrm{A})$ $=3.54172 \mathrm{C}(\mathrm{mM})+258.914\left(\mathrm{R}^{2}=0.961\right)$ within the concentration range of $0.002 \sim 50 \mathrm{mM}$. The limit of detection (LOD) for 1-modified GCE toward DA is calculated as $8.7 \mu \mathrm{M}$, which 
demonstrates that 1-modified GCE displayed good sensitivity towards the determination of DA.

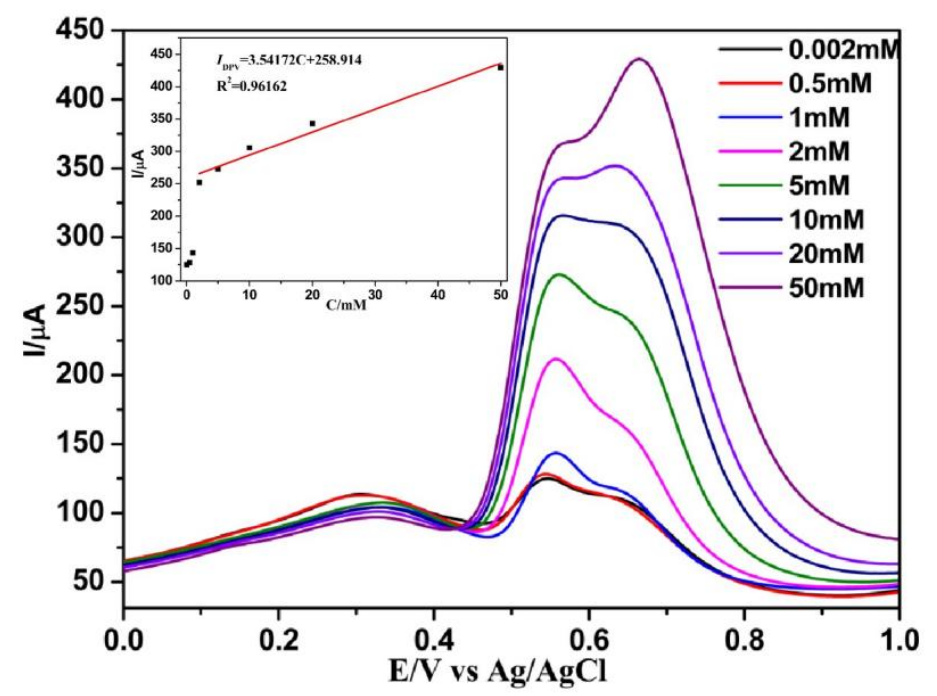

Figure 6. Differential pulse voltammograms of 1-modified GCE in $\mathrm{H}_{2} \mathrm{SO}_{4}$ aqueous solution $\left(0.1 \mathrm{molL}^{-1}\right)$ with increasing concentrations of DA from 0.002 to $50 \mathrm{mM}$. Insets: linear relations of DPV peak currents for 1-modified GCE with the increasing of DA.

\section{Materials and Methods}

Experiments. All chemical reagents were purchased analytical purity grade and without further purification before use. IR spectrum was obtained from KBr pellet with a Nicolet 170 SXFT-IR spectrophotometer from Bruker of Germany in the range of 4000 500 $\mathrm{cm}^{-1}$ region. Analysis of $\mathrm{C}, \mathrm{H}$ and $\mathrm{N}$ elements were performed on a Perkin-Elmer 240C instrument from Waltham, MA, America. The powder X-ray diffraction (PXRD) pattern was measured using Bruker D8 Advance produced Bruker of Germany. The UV-vis spectrum was carried out on a PE LAMBDA 950 UV/Vis/NIR spectrophotometer from Perkin-Elmer of America in the range of $800 \sim 200 \mathrm{~nm}$ in the solid state. The thermostability was tested by Bruker Tensor-II produced in Bruker, Germany. The electrochemical behavior was investigated on a CHI660E electrochemical workstation from Chenhua in Shanghai, China in $0.1 \mathrm{~mol} \cdot \mathrm{L}^{-1} \mathrm{H}_{2} \mathrm{SO}_{4}$ aqueous solution, using a carbon paste electrode (CPE) modified by compound 1 as working electrode, $\mathrm{Ag} / \mathrm{AgCl}$ electrode as a reference electrode and $\mathrm{Pt}$ electrode as the counter electrode.

Synthesis. Compound 1 was synthesized in aqueous solution. $\mathrm{NH}_{4} \mathrm{VO}_{3}(58.7 \mathrm{mg}$, $0.5 \mathrm{mmol}), \mathrm{NaOH}(32 \mathrm{mg}, 0.8 \mathrm{mmol})$, phen $(19.9 \mathrm{mg}, 0.1 \mathrm{mmol})$ and $\mathrm{Zn}\left(\mathrm{CH}_{3} \mathrm{COO}\right)_{2}(43.8 \mathrm{mg}$, $0.2 \mathrm{mmol}$ ) were successively dissolved in $19 \mathrm{~mL}$ distilled water. Then $1 \mathrm{~mL} \mathrm{CH} \mathrm{CH}_{2} \mathrm{OH}$ was added to the mixed solution, generating white precipitate. The $\mathrm{pH}$ value of the resulting solution was adjusted to 10.5 using approximately $0.35 \mathrm{~mL}$ of triethylenetetramine and then added $0.3 \mathrm{~mL}$ acetic acid to adjust $\mathrm{pH}$ to be 7.0 . After stirring for $30 \mathrm{~min}$ at ambient temperature, the solution was heated at $90{ }^{\circ} \mathrm{C}$ for $60 \mathrm{~min}$ and then filtered when it was cooled to room temperature. The filtrate was left to slowly evaporate at room temperature and pink crystals of 1 were obtained for two weeks in $72 \%$ yield. Elemental analysis calcd (\%) for $\mathrm{C}_{84} \mathrm{~N}_{14} \mathrm{H}_{96} \mathrm{Zn}_{2} \mathrm{~V}_{4} \mathrm{O}_{32}(M=2148.24)$ : C 46.92, $\mathrm{H} 4.46, \mathrm{~N} 9.12$; found: $\mathrm{C} 47.02$, H 4.35, N 9.05.

IR (KBr; v cm $\left.{ }^{-1}\right)$ : 3400 vs, 3057 m, 1625 m, 1585 w, 1518 s, 1426 vs, 1340 w, 1307 w, 1225 w, 1146 w, 1104 m, 940 m, 910 s, 867 s, 846 vs, 805 vs, 724 vs, 643 m, 509 w.

X-ray crystallography. A crystal with a size of $0.46 \times 0.40 \times 0.36 \mathrm{~mm}^{3}$ was placed on a Bruker Smart APEX II CCD diffractometer from Bruker of Germany with $\omega$ and $\varphi$ scan mode in the range of $2.33^{\circ}<\theta<27.12^{\circ}$. The diffraction intensity of compound 1 were carried out at room temperature using graphite-monochromatized MoK $\alpha$ radiation $(\lambda=0.71073 \AA)$. The analysis of crystal structure was carried out by Direct Methods and 
refined on $F^{2}$ by full-matrix least-squares with the SHELXL-97 program [44]. All nonhydrogen atoms were refined anisotropically by full-matrix least-squares techniques, while all hydrogen atoms were fixed to calculated positions but there is no refinement in the calculation of the structure factors. Space group, lattice parameters and other relevant information are listed in Table 2. The relevant bond lengths and bond angles are listed in Table S1.

Table 2. Summary of crystal data and refinement results of $\mathbf{1}$.

\begin{tabular}{cc}
\hline Chemical Formula & $\mathbf{C}_{\mathbf{8 4}} \mathbf{N}_{\mathbf{1 4}} \mathbf{H}_{\mathbf{9 6}} \mathbf{Z} \mathbf{n}_{\mathbf{2}} \mathbf{V}_{\mathbf{4}} \mathbf{O}_{\mathbf{3 2}}$ \\
\hline Formula weight & 2148.24 \\
Crystal system & Triclinic \\
Space group & $P^{-} 1 P^{-} 1$ \\
$a, \AA$ & $12.9427(8)$ \\
$b, \AA$ & $17.6899(11)$ \\
$c, \AA$ & $23.5108(14)$ \\
$\alpha{ }^{\circ}$ & $106.4910(10)$ \\
$\beta /{ }^{\circ}$ & $91.0390(10)$ \\
$\gamma /{ }^{\circ}$ & $106.8800(10)$ \\
$V, \AA^{3}$ & $4909.4(5)$ \\
$Z$ & 2 \\
$T, \mathrm{~K}$ & $296(2)$ \\
$D_{\text {calc' }} \mathrm{g}$ cm & 1.453 \\
$F(000)$ & 2212 \\
range for data collection $/{ }^{\circ}$ & $1.262-25.499$ \\
Refinement method & Full-matrix least-squares on $F^{2}$ \\
Goodness of fit on $F^{2}$ & 1.019 \\
Final $R$ indices $[I>2 s(I)]$ & $R_{1}=0.0530, w R_{2}=0.1058$ \\
\hline
\end{tabular}

CCDC 1956066 contains the supplementary crystallographic data. These data can be obtained free of charge from The Cambridge Crystallographic Data Centre via www.ccdc. cam.ac.uk/data_request/cif on 12 January 2022.

\section{Conclusions}

In conclusion, a new organic-inorganic hybrid $\left[\mathrm{Zn}(\mathrm{phen})_{3}\right]_{2} \cdot\left(\mathrm{V}_{4} \mathrm{O}_{12}\right) \cdot$ phen $\cdot 20 \mathrm{H}_{2} \mathrm{O}$ (phen $=1,10$-phenathroline) (1), were assembled by conventional aqueous solution. It was found that the structure of compound 1 contains two $\left[\mathrm{V}_{4} \mathrm{O}_{12}\right]^{4-}$ types of chair-like and coplanar conformations, which is rare in crystal engineering. Moreover, the electrocatalytic activity toward DA and AA were for the first time investigated and display good performance on the oxidation of DA and AA. More importantly, 1-modified GCE has better sensitivity for the determination of DA and the limit is calculated as $8.7 \mu \mathrm{M}$, which demonstrate that compound $\mathbf{1}$ is not only a stable electrocatalyst, but also has potential applications in the detection of DA.

Supplementary Materials: The following supporting information can be downloaded at: https: //www.mdpi.com/article/10.3390/catal12020108/s1, Figures S1-S8: Relevant structural figures, PXRD, IR spectrum, UV/Vis spectrum, SEM image, TG curve, CV of compound 1 in $\mathrm{H}_{2} \mathrm{SO}_{4}$ aqueous solution after 100 consecutive cycles; Table S1: Bond lengths and bond angles of compound 1.

Author Contributions: Conceptualization, Y.B. and D.D.; methodology, J.P. and H.L.; validation, J.P.; formal analysis, Y.F.; investigation, Y.W. and B.Z.; writing-original draft preparation, Y.W.; writing—review and editing, H.G.; visualization, Y.W.; supervision, Y.B.; project administration, J.P.; funding acquisition, Y.B. and D.D. All authors have read and agreed to the published version of the manuscript.

Funding: The author thanks the support of the National Natural Science Foundation of China (No. 21971055), the Natural Science Foundation of Henan Province (212300410334), the Foundation of the Education Department of Henan Province of China (21A150011), the Postdoctoral Science 
Foundation of China (No. 2019M652518), and the Postdoctoral Scientific Research Foundation of Henan Province.

Data Availability Statement: The data presented in this study are available in article.

Acknowledgments: We would like to thank the teachers of the Henan Key Laboratory of Polyoxometalate Chemistry, College of Chemistry and Chemical Engineering, Henan University for their support in the inspection equipment used for experiments.

Conflicts of Interest: The authors declare no conflict of interest.

\section{References}

1. Mulkapuri, S.; Kurapati, S.K.; Das, S.K. Carbonate encapsulation from dissolved atmospheric $\mathrm{CO}_{2}$ into a polyoxovanadate capsule. Dalton Trans. 2019, 48, 8773-8781. [CrossRef] [PubMed]

2. Hu, X.K.; Wang, H.; Huang, B.; Li, N.; Hu, K.H.; Wu, B.L.; Xiao, Z.C.; Wei, Y.H.; Wu, P.F. A new scheme for rational design and synthesis of polyoxovanadate hybrids with high antitumor activities. J. Inorg. Biochem. 2019, 193, 130-132. [CrossRef] [PubMed]

3. Xin, X.; Tian, X.R.; Zhang, H.; Gao, Y.Z.; Ma, Y.Y.; Han, Z.G. Synthesis and characterization of Ag-ligand modified polyoxovanadates with three-dimensional structures. J. Solid State Chem. 2019, 269, 278-284. [CrossRef]

4. Batrice, R.J.; Wacker, J.N.; Glass, E.N.; Jilani, S.Z.; Tong, Y.Y.J.; Nyman, M.; Knope, K.E. Template-free cyclic hexavanadate: Synthesis, characterization, solid-state structure, and solution-state dynamics. Polyhedron 2019, 169, 266-277. [CrossRef]

5. Liu, Y.; Li, J.; Sun, D.; Men, L.L.; Sun, B.; Li, X.; An, Q.B.; Liu, F.B.; Su, Z.M. Self-assembly of bimetallic polyoxometalates and dicyandiamide to form co/wc@nc for efficient electrochemical hydrogen generation. New J. Chem. 2022, 46, 178-184. [CrossRef]

6. Chen, B.K.; Huang, X.Q.; Wang, B.; Lin, Z.G.; Hu, J.F.; Chi, Y.N.; Hu, C.W. Three New Imidazole-Functionalized Hexanuclear Oxidovanadium Clusters with Exceptional Catalytic Oxidation Properties for Alcohols. Chem. Eur. J. 2013, 19, $4408-4413$. [CrossRef]

7. Zhou, J.; Zhao, J.W.; Wei, Q.; Zhang, J.; Yang, G.Y. Two Tetra-Cd ${ }^{\mathrm{II}}$-Substituted Vanadogermanate Frameworks. J. Am. Chem. Soc. 2014, 136, 5065-5071. [CrossRef]

8. Cao, J.P.; Xue, Y.S.; Hu, Z.B.; Luo, X.M.; Cui, C.H.; Song, Y.; Xu, Y. Exploring the Magnetic Interaction of Asymmetric Structures Based on Chiral VIII8 Clusters. Inorg. Chem. 2019, 58, 2637-2644. [CrossRef]

9. Linnenberg, O.; Kozłowski, P.; Besson, C.; Leusen, J.V.; Englert, U.; Monakhov, K.U. A V 16 -type Polyoxovanadate Structure with Intricate Electronic Distribution: Insights from Magnetochemistry. Cryst. Growth Des. 2017, 17, 2342-2350. [CrossRef]

10. Zhang, X.; You, W.S.; Zhu, Z.M.; Dang, L.Q.; Sun, Z.G.; Zheng, X.F. Hydrothermal synthesis and characterization of a novel crystal containing $\left[\mathrm{Co}_{4} \mathrm{O}_{4}\right]^{4+}$ cubane core: $\left[\mathrm{Co}_{4} \mathrm{O}_{4}(\mathrm{dpaH})_{4}\left(\mathrm{CH}_{3} \mathrm{COO}\right)_{2}\right]_{2} \mathrm{~V}_{4} \mathrm{O}_{12} \cdot 5 \mathrm{H}_{2} \mathrm{O}$. Inorg. Chem. Commun. 2006, 9, 526-528. [CrossRef]

11. Zhou, Y.Y.; Yao, S.; Yan, J.H.; Chen, L.; Wang, T.T.; Wang, C.J.; Zhang, Z.M. Design and synthesis of purely inorganic 3D frameworks composed of reduced vanadium clusters and manganese linkers. Dalton Trans. 2015, 44, 20435-20440. [CrossRef]

12. Zhang, G.H.; Shi, Z.; Xu, Y.H.; Feng, S.H. An Organically Templated Cobalt-Vanadium Oxide with â Cage Units: Hydrothermal Synthesis and $X$-ray Structural Characterization of $\left(\mathrm{C}_{2} \mathrm{H}_{10} \mathrm{~N}_{2}\right)\left[\mathrm{Co}_{2}\left(\mathrm{C}_{2} \mathrm{O}_{4}\right) \mathrm{V}_{4} \mathrm{O}_{12}\right]$. Inorg. Chem. 2003, 42, 1170-1174.

13. Zhang, S.Y.; Guo, W.B.; Tang, Y.Y.; Xu, J.Q.; He, Z.Z. Observation of Spin Relaxation in a Vanadate Chloride with Quasi One-Dimensional Linear Chain. Cryst. Growth Des. 2019, 19, 2228-2234. [CrossRef]

14. Qin, J.S.; Du, D.Y.; Li, S.L.; Lan, Y.Q.; Shao, K.Z.; Su, Z.M. pH-Tuned self-assembly of organic-inorganic hybrids based on different vanadate chains, $\mathrm{Zn}(\mathrm{II})$ ions and flexible ligands: Crystallizing in polar and centrosymmetric space group. CrystEngComm 2011, 13, 779-786. [CrossRef]

15. Paredes-García, V.; Gaune, S.; Saldías, M.; Garland, M.T.; Baggio, R.; Vega, A.; Salah El Fallah, M.; Escuer, A.; Fur, L.E.; Yazigi, D.V.; et al. Solvatomorphs of dimeric transition metal complexes based on the $\mathrm{V}_{4} \mathrm{O}_{12}$ cyclic anion as building block: Crystalline packing and magnetic properties. Inorg. Chim. Acta 2008, 361, 3681-3689. [CrossRef]

16. Wang, K.; Xu, Q.F.; Ma, P.T.; Zhang, C.; Niu, J.Y.; Wang, J.P. Polyoxovanadate catalysts for oxidation of 1-phenyl ethanol: From the discrete $\left[\mathrm{V}_{4} \mathrm{O}_{12}\right]^{4-}$ and $\left[\mathrm{V}_{10} \mathrm{O}_{28}\right]^{6-}$ anions, to the anionic $\left[\mathrm{V}_{6} \mathrm{O}_{17}\right]_{\mathrm{n}}{ }^{4 \mathrm{n}-}$ coordination polymer. CrystEngComm 2018, 20, 6273-6279. [CrossRef]

17. Roman, P.; Jose, A.S.; Luque, A.; Gutierrez-Zorrilla, J.M. Observation of a Novel Cyclic Tetrametavanadate Anion Isolated from Aqueous Solution. Inorg. Chem. 1993, 32, 775-776. [CrossRef]

18. Fuchs, J.; Mahjour, S.; Pickardt, J. Structure of the "True" Metavanadate Ion. Angew. Chem. Int. Ed. 1976, 15, 374-375. [CrossRef]

19. Tang, Q.L.; Zhou, J.; Liu, X.; Xiao, H.; Li, W.B.; Fu, L.S.; Dong, T.T. A novel 2-D heterometallic polymer containing two types of 1-D cuprous polymeric chains and circle $\left[\mathrm{V}_{4} \mathrm{O}_{12}\right]^{4-}$ clusters. J. Alloys Compd. 2017, 713, 46-50. [CrossRef]

20. Qi, Y.F.; Lv, C.P.; Li, Y.G.; Wang, E.B.; Li, J.; Song, X.L. A new three-dimensional 4,6-connected self-catenated net constructed from the $\left[\mathrm{V}_{8} \mathrm{O}_{23}\right]^{6-}$ polyoxoanions and metal-organic polymer. Inorg. Chem. Commun. 2010, 13, 384-387.

21. Kastner, K.; Puscher, B.; Streb, C. Self-assembly of a tetrahedral 58-nuclear barium vanadium oxide cluster. Chem. Commun. 2013, 49, 140-142. [CrossRef]

22. Chen, L.; Jiang, F.L.; Lin, Z.Z.; Zhou, Y.F.; Yue, C.Y.; Hong, M.C. A Basket Tetradecavanadate Cluster with Blue Luminescence. J. Am. Chem. Soc. 2005, 127, 8588-8589. [CrossRef] 
23. Karet, G.B.; Sun, Z.; Streib, W.E.; Bollinger, J.C.; Hendrickson, D.N.; Christou, G. Stepwise assembly of a polyoxovanadate from mononuclear units in an organic solvent: Carboxylate-stabilised fragments in the conversion of $\left[\mathrm{VOC}_{14}\right]^{22-}$ to $\left[\mathrm{V}_{15} \mathrm{O}_{36}\right]^{52-}$. Chem. Commun. 1999, 2249-2250. [CrossRef]

24. Wang, K.; Niu, Y.J.; Zhao, D.Y.; Zhao, Y.X.; Ma, P.T.; Zhang, D.D.; Wang, J.P.; Niu, J.Y. The Polyoxovanadate-Based Carboxylate Derivative $\mathrm{K}_{6} \mathrm{H}\left[\mathrm{V}^{\mathrm{V}}{ }_{17} \mathrm{~V}^{\mathrm{IV}}{ }_{12}(\mathrm{OH})_{4} \mathrm{O}_{60}\left(\mathrm{OOC}\left(\mathrm{CH}_{2}\right)_{4} \mathrm{COO}\right)_{8}\right] \cdot \mathrm{nH}_{2} \mathrm{O}$ : Synthesis, CrystalStructure, and Catalysis for Oxidation of Sulfifides. Inorg. Chem. 2017, 56, 14053-14059. [CrossRef]

25. Zhang, P.P.; Peng, J.; Pang, H.J.; Chen, Y.; Zhu, M.; Wang, D.D.; Liu, M.G.; Wang, Y.H. A Cu coordination polymer-modified $\left[\mathrm{V}_{4} \mathrm{O}_{12}\right]^{4-}$ polyanion with interdigitated architecture. Inorg. Chem. Commun. 2010, 13, 1414-1417. [CrossRef]

26. Zurkova, L.; Kucsera, R.; Gyepes, R.; Sivák, M. Synthesis and X-Ray Crystal Structure of Two Novel Complexes: $\left[\mathrm{M}^{\mathrm{II}}\left(\mathrm{phen}_{3}\right]_{2} \mathrm{~V}_{4} \mathrm{O}_{12}\right.$ phen $22 \mathrm{H}_{2} \mathrm{O}\left(\mathrm{M}^{\mathrm{II}}=\mathrm{Co}, \mathrm{Ni}\right.$; phen = phenanthroline $)$. Mon. Chem. 2003, 134, 1071-1079. [CrossRef]

27. Joniakova, D.; Gyepes, R.; Rakovsky, E.; Schwendt, P.; Zurkova, L.; Marek, J.; Micka, Z. Structural variability of copper-1,10phenanthroline-oxovanadate hybrid inorganic-organic compounds. Polyhedron 2006, 25, 2491-2502. [CrossRef]

28. Xu, X.H.; Cao, Q.L.; Luo, F.; Wang, G. Synthesis and Crystal Structure of the Bimetallic Complex $\left[\mathrm{Fe}(\mathrm{phen})_{3}\right]_{2}[\mathrm{phen}]\left[\mathrm{V}_{4} \mathrm{O}_{12}\right] \cdot 19 \mathrm{H}_{2} \mathrm{O}$. Z. Nat. 2008, 63, 1352-1356. [CrossRef]

29. Gu, W.; Bian, H.D.; Xu, J.Y.; Yan, S.P.; Liao, D.Z.; Jiang, Z.H. Hydrothermal synthesis, structure, spectroscopic and magnetic properties of a hexanuclear cluster: [ $\left.\left\{\mathrm{Mn}\left(2,2^{\prime} \text {-bipy }\right)_{2}\right\}_{2} \mathrm{~V}_{4} \mathrm{O}_{12}\right]$. Inorg. Chem. Commun. 2003, 6, 217-220. [CrossRef]

30. Dang, D.B.; Zheng, Y.N.; Bai, Y.; Guo, X.Y.; Ma, P.T.; Niu, J.Y. Assembly of Polyoxometalate-Based Metal-Organic Frameworks with Silver(I)-Schiffff Base Coordination Polymeric Chains as Building Blocks. Cryst. Growth Des. 2012, 12, 3856-3867. [CrossRef]

31. Bai, Y.; Zhang, G.Q.; Dang, D.B.; Ma, P.T.; Gao, H.; Niu, J.Y. Assembly of polyoxometalate-based inorganic-organic compounds from silver-Schiff base building blocks: Synthesis, crystal structures and luminescent properties. CrystEngComm 2011, 13, 4181-4187. [CrossRef]

32. Dang, D.B.; An, B.; Bai, Y.; Niu, J.Y. Assembly of a phospho-molybdic Wells-Dawson-based silver coordination polymer derived from Keggin polyoxoanion cluster. Dalton Trans. 2012, 41, 13856-13861. [CrossRef]

33. Dang, D.B.; Zheng, G.S.; Bai, Y.; Yang, F.; Gao, H.; Ma, P.T.; Niu, J.Y. Construction of Polyoxometalate-Based Inorganic Organic Compounds Using Silver(I) Double Helicates as Secondary Building Blocks. Inorg. Chem. 2011, 50, 7907-7909. [CrossRef]

34. Li, L.; Cheng, M.; Bai, Y.; An, B.; Dang, D.B. A polyoxometalate-based inorganic-organic hybrid polymer constructed from silver-Schiff base building block and Keggin-type cluster: Synthesis, crystal structure and photocatalytic performance for the degradation of rhodamine B. Spectrochim. Acta A 2015, 150, 846-854. [CrossRef]

35. Shi, S.K.; Guo, Z.; Feng, R.; Jin, L.Y.; Bai, Y.; Dang, D.B. Hydrothermal synthesis and crystal structure of a bisupporting Keggin-polyoxometalate hybrid compound decorated with a copper(II) complex unit. Z. Nat. 2018, 73, 197-202. [CrossRef]

36. Chen, W.H.; Hu, Z.B.; Zhang, Z.S.; Qiu, Z.H.; Zhao, J.H.; Lai, Y.Z.; Mi, J.X. Synthesis, Structure, Characterizations and Photocatalytic Degradation of a New POM-Based Hybrid Compound: (Hdma) $)_{4}\left[\mathrm{Cd}(\mathrm{phen})_{3}\right]\left[\mathrm{W}_{18} \mathrm{O}_{54}\left(\mathrm{PO}_{4}\right)_{2}\right] 2 \mathrm{H}_{2} \mathrm{O}$. J. Clust. Sci. 2017, 28, 1113-1123. [CrossRef]

37. Xiao, L.N.; Hu, Y.Y.; Wang, L.M.; Wang, Y.; Xu, J.N.; Ding, H.; Cui, X.B.; Xu, J.Q. New compounds based on polyoxometalates and metal halide clusters. CrystEngComm 2012, 14, 8589-8598. [CrossRef]

38. Guo, H.Y.; Zhang, T.T.; Lin, P.H.; Zhang, X.; Cui, X.B.; Huo, Q.S.; Xu, J.Q. Preparation, structure and characterization of a series of vanadates. CrystEngComm 2017, 19, 265-275. [CrossRef]

39. Yu, Z.F.; Ke, D.G.; Huang, B.; Zhang, Y.T.; Luo, Z.H.; Wang, H.; Xiao, Z.C. Spectroscopic Studies of a Novel Inorganic-Organic Hybrid Based on Polyoxovanadates under a Wide Range of Wavelengths. J. Clust. Sci. 2019, 30, 5-10. [CrossRef]

40. Li, C.X.; Zhang, Y.; O'Halloran, K.P.; Zhang, J.W.; Ma, H.Y. Electrochemical behavior of vanadium-substituted Keggin-type polyoxometalates in aqueous solution. J. Appl. Electrochem. 2009, 39, 421-427. [CrossRef]

41. Rajamani, A.R.; Peter, S.C. Novel nanostructured Pt/ $\mathrm{CeO}_{2} @ \mathrm{Cu}_{2} \mathrm{O}$ carbon-based electrode to magnify the electrochemical detection of theneurotransmitter dopamine and analgesic paracetamol. ACS Appl. Nano Mater. 2018, 1, 5148-5157. [CrossRef]

42. Wang, Q.W.; Jessie, K.; Li, L.; Liu, Y.; Wang, X.H.; Wang, S.T. Fabrication of polyoxometalate/GO/PDDA hybrid nanocomposite modifified electrode and electrocatalysis for nitrite ion, ascorbic acid and dopamine. J. Electroanal. Chem. 2018, 824, 91-98. [CrossRef]

43. Fernandes, D.M.; Barbosa, A.D.S.; Pires, J.; Balula, S.S.; Cunha-Silva, L.; Freire, C. Novel composite material polyoxovanadate@mil101(cr): A highly efficient electrocatalyst for ascorbic acid oxidation. ACS Appl. Mater. Interfaces 2013, 5, 13382-13390. [CrossRef]

44. Sheldrick, G.M. SHELXS-97, Program for Crystal Structure Solution; University of Göttingen: Göttingen, Germany, 1997. 